\title{
Effects of Green Manure Type and Amendment Rate on Verticillium Wilt Severity and Yield of Russet Burbank Potato
}

\author{
N. Ochiai, Department of Crop and Soil Science, and M. L. Powelson, Department of Botany and Plant Pathology, \\ Oregon State University, Corvallis 97331; R. P. Dick, School of Natural Resources, Ohio State University, Colum- \\ bus 43210-1085; and F. J. Crowe, Department of Botany and Plant Pathology, Oregon State University, Central Ore- \\ gon Agricultural Research Center, Madras 97441
}

\begin{abstract}
Ochiai, N., Powelson, M. L., Dick, R. P., and Crowe, F. J. 2007. Effects of green manure type and amendment rate on Verticillium wilt severity and yield of Russet Burbank potato. Plant Dis. 91:400-406

Increasing restriction of agrochemicals is motivating development of ecology-based cropping systems, including green manures, to manage soilborne diseases. Green manures have shown promise in suppressing Verticillium dahliae, but information about effect of different green manures and optimal application rates remains limited. Therefore, we conducted two single-year field experiments comparing effects of Austrian winter pea (Pisum sativum 'Melrose'), broccoli (Brassica oleracea var. botrytis 'Excelsior'), and Sudan grass (Sorghum vulgare var. sudanense 'Monarch'), amended at 6,12 , or $24 \mathrm{Mg} \mathrm{ha}^{-1}$, on soil populations and root infection by V. dahliae, wilt severity, and yield of Russet Burbank potato. Inoculum density was reduced relative to the nonamended, infested control by all broccoli treatments, Austrian winter pea applied at 12 and $24 \mathrm{Mg} \mathrm{ha}^{-1}$, and Sudan grass applied at $12 \mathrm{Mg} \mathrm{ha}^{-1}$. Root infection was not reduced by any green manure treatment. Median wilt severity was reduced approximately $70 \%$ by all green manures applied at $24 \mathrm{Mg} \mathrm{ha}^{-1}$ and $74 \%$ by Austrian winter pea applied at $12 \mathrm{Mg} \mathrm{ha}^{-1}$. Tuber yield was reduced approximately $20 \%$ in nonamended, $V$. dahliae-infested controls relative to the noninfested controls. No green manure treatment improved yield relative to the nonamended, infested control.
\end{abstract}

Additional keywords: cover crop, disease suppression

Verticillium wilt, caused by Verticillium dahliae Kleb., is a major disease of many cultivated plant species, including potato, throughout temperate regions of the world (47). In North America, potato yield reduction due to Verticillium wilt can range from 10 to $50 \%$ (37). The long-term persistence of the pathogen in the soil (56) and its wide host range, including some bridging hosts (16), complicate use of crop rotation for managing this disease (39). In North America, periodic reduction of soil populations of $V$. dahliae by soil fumigation is widely practiced as a means of managing this disease (39). In recent years, however, greater regulation of agrochemicals and increasing costs of application are motivating the development of alternative management strategies.

Green manures and other organic matter (OM) amendments have been used to improve soil tilth and fertility since early times (29). Studies conducted in the midtwentieth century demonstrated the poten-

Corresponding author: N. Ochiai

E-mail: ochiain@onid.orst.edu

Accepted for publication 12 October 2006.

doi:10.1094/PDIS-91-4-0400

(C) 2007 The American Phytopathological Society tial of OM amendments to promote plant health by suppressing diseases caused by soilborne pathogens $(20,31,55)$. Numerous soil amendments have been evaluated for their potential to suppress Verticillium wilt, including animal manures (5), composted materials (27), industrial byproducts $(38)$, and green manures $(1,11,15,35)$. Different amendments have resulted in a range of responses from nearly complete suppression (5) to no effect (35) or increased severity (38), with the majority resulting in partial reduction of disease $(1,11,15)$.

Characteristics of $\mathrm{OM}$ that determine their efficacy in suppressing Verticillium wilt and the underlying mechanisms of suppression are not fully understood. From previous research, it appears that at least two modes of suppression exist. Suppression of Verticillium wilt by broccoli residues or animal manures is attributed to reduction of soil populations of $V$. dahliae $(5,46)$. In these cases, it is believed that compounds toxic to $V$. dahliae are released during decomposition of the amendment $(28,46,52)$. For other amendments-such as Sudan grass, Austrian winter pea, sweet corn, or barley residues-there was no association between reduction in inoculum density (ID) and suppression of Verticillium wilt $(9,11,12)$ or the association was not determined (27).
In cases of OM-mediated suppression of other diseases, degree of disease reduction often appears to be related to the amount of material amended $(7,8,14,21,33,49)$. In an in vitro study, Berlanger (1) demonstrated a positive correlation between amendment rate of broccoli residue and reduction of soil populations of $V$. dahliae. In a greenhouse study, Davis et al. (10) observed a negative correlation between the amount of Sudan grass residue amended and severity of Verticillium wilt of potato. The rate effect likely is related to a general suppression, where increased carbon inputs increases microbial activity and soil quality. However, there is limited information about the quantitative relationship between amendment rate and suppression of Verticillium wilt $(1,10)$, particularly at the field scale.

Although the use of green manures to suppress Verticillium wilt shows promise, the phenomenon remains poorly understood and has had inconsistent results. Information is needed on the disease suppressive potential of diverse plant materials that can be grown on site. In addition, although it is suspected that increased amendment rates will result in greater suppression of Verticillium wilt, it is not known to what degree suppression depends on the amount of biomass amended rather than the type of material amended. At the same time, the response of soil properties can provide insights into suppressive mechanisms. Therefore, the objective of this investigation was to evaluate the effect of three green manures amended at three rates on ID, root infection by $V$. dahliae, severity of Verticillium wilt, and tuber yield of Russet Burbank potato.

\section{MATERIALS AND METHODS}

Experimental design. Field experiments were conducted in 2002 and 2003 in adjacent fields at the Central Oregon Agricultural Research Center in Madras, OR. The experimental design was a randomized complete block (RCB) with four replications. Treatments comprised a 3-by-3 factorial with three types of green manure amended at three rates into soil infested with $V$. dahliae microsclerotia, a nonamended infested control, and four noninfested controls. The three types of green manure used, representing the three plant families Leguminosae, Brassicaceae, and 
Graminacae, were Austrian winter pea (Pisum sativum L. 'Melrose'), broccoli (Brassica oleracea L. var. botrytis L. 'Excelsior'), and Sudan grass (Sorghum vulgare Pers. var. sudanense (piper) Hitche 'Monarch'), respectively; the three amendment rates were 6,12 , and $24 \mathrm{Mg}$ $\mathrm{ha}^{-1}$ dry biomass; three of the noninfested controls received one each of the green manures at $12 \mathrm{Mg} \mathrm{ha}^{-1}$ and the fourth received no green manure (nonamended). Austrian winter pea is considered a winter cover crop which can improve nitrogen fertility after incorporation. Broccoli is commonly grown as a crop, but the remaining aboveground matter potentially could be plowed down after harvest. Sudan grass is considered a suitable green manure for hot, dry climates, producing a significant amount of biomass. The lowest amendment rate $\left(6 \mathrm{Mg} \mathrm{ha}^{-1}\right)$ used was considered to be a reasonable estimate of dry-matter accumulation for a typical green manure in a single season based on various published reports $(17,30)$.

Infestation and green manure incorporation. The experimental fields, mapped as Madras series sandy loam (superacitve, mesic, Aridic Argixeroll), had not been cropped previously to potato or other hosts of $V$. dahliae, and background levels of $V$. dahliae, determined by plating samples of air-dried soil collected from random locations within each field, were low (1.8 and $0.8 \mathrm{CFU} \mathrm{g}^{-1}$ of soil in 2002 and 2003, respectively). Microsclerotia of VCG4 (potato strain) of $V$. dahliae were cultivated on potato dextrose agar and harvested in the manner described by Gaudreault et al. (18). In August of the year preceding potato cultivation, microsclerotia mixed with fine sand were spread by hand on the experimental microplots ( 3 by $3.7 \mathrm{~m}$ ) to achieve an approximate density of 25 to 30 $\mathrm{CFU} \mathrm{\textrm {g } ^ { - 1 }}$ of soil, which is a level expected to cause significant Verticillium wilt severity. Austrian winter pea, broccoli, and Sudan grass were grown for approximately 45 days in large blocks outside of the experimental sites in the summer of the year preceding potato cultivation. In August, at the same time as infestation of soil with $V$. dahliae, the aerial biomass of the three green manures was chopped in the field with a tractor flail, collected, and spread within $2 \mathrm{~h}$ on plots at one of three rates $(6$, 12 , or $24 \mathrm{Mg} \mathrm{ha}^{-1}$ dry matter). Both microsclerotia and green manures were immediately disc-incorporated to a depth of 25 to $30 \mathrm{~cm}$.

Cultural practices for potato. In the spring prior to planting, each plot received a base application of $\mathrm{N}, \mathrm{P}_{2} \mathrm{O}_{5}$, and $\mathrm{K}_{2} \mathrm{O}$ at $203 \mathrm{~kg} \mathrm{ha}^{-1}$ each and $\mathrm{S}$ at $89 \mathrm{~kg} \mathrm{ha}^{-1}$ in 2002 , and $\mathrm{N}, \mathrm{P}_{2} \mathrm{O}_{5}$, and $\mathrm{K}_{2} \mathrm{O}$ at $174 \mathrm{~kg} \mathrm{ha}^{-1}$ each and $\mathrm{S}$ at $189 \mathrm{~kg} \mathrm{ha}^{-1}$ in 2003, based on soil tests following amendment. Generation III seed potato (Solanum tuberosom cv. Russet Burbank) were hand cut into seed pieces weighing 43 to $71 \mathrm{~g}$ and were planted on 8 May 2002 and 7 May 2003. Seed pieces were planted in plots consisting of four 3-m long rows. Row width was $93 \mathrm{~cm}$ and seed pieces were spaced $23 \mathrm{~cm}$ apart within the row. Plots were sprinkler irrigated throughout the season as necessary.

Soil sampling and analyses. Ten soil cores were taken with a 2.5 -cm-diameter soil probe at a depth of 0 to $15 \mathrm{~cm}$ approximately 1 month after incorporation of the green manures (27 September 2001 and 25 September 2002), prior to planting potato (23 April 2002 and May 7 2003), and 3 weeks after the emergence of potato plants (25 June 2002 and 16 June 2003). Soil cores from each plot were composited, passed through a 4-mm sieve, and air dried at room temperature or, in the case of microbial analyses, processed within 2 days while the soil was still moist.

Soil $\mathrm{pH}$ was measured in a 1:2(wt/vol) solution of $0.05 \mathrm{M} \mathrm{CaCl}_{2}$ using an Orion $\mathrm{pH}$ meter. Exchangeable cations were extracted with $\mathrm{KCl}$ and analyzed by inductively coupled plasma spectrometry (ICP$\mathrm{AES}$ ) at the Central Analytical Laboratory, Oregon State University, in 2002, and at the W. M. Keck Collaboratory, Oregon State University, in 2003. Total organic carbon (TOC) was analyzed by dry combustion as described by Nelson and Sommers (32).

Fluorescein diacetate (FDA) hydrolysis of soils sampled in summer was assessed colorimetrically using a method modified from Schnürer and Rosswall (42) within $10 \mathrm{~h}$ of collection. Microbial respiration (MR) and microbial biomass carbon (MBC) of soils sampled in spring were assessed simultaneously using the chloroform-fumigation-incubation method (23).

Pathogen, disease, and yield assessment. Inoculum density was assessed by plating air-dried soil onto NP10 medium (48) using an Andersen Air sampler (4). Each sample consisted of five plates with approximately $0.36 \mathrm{~g}$ of soil per plate. Plates were incubated for a minimum of 10 days in the dark at room temperature and rinsed with running tap water to remove soil particles from the agar surface. The number of $V$. dahliae colonies on each plate was counted using a stereomicroscope and expressed as CFU per gram of soil.

Two plants were dug from the middle two rows of each plot 3 weeks after emergence and the root ball removed. Root balls were transported in a cooler to Oregon State University and rinsed with distilled water containing a small amount of tergitol to remove soil particles. Fine roots were collected on a number-10 sieve and cut into $1001-\mathrm{cm}$ sections which were plated onto NP10 medium (48). Plates were incubated in the dark at room temperature for at least 10 days, after which the number of $V$. dahliae colonies emerging from plated root pieces was counted and expressed as CFU per meter of root.
Beginning with the appearance of disease symptoms (foliar chlorosis or necrosis), wilt severity for each plot was assessed on a scale of 0 to $100 \%$, where $0 \%$ $=$ no symptoms and $100 \%=$ all foliage senescent or wilted. Disease readings were taken weekly for 5 weeks.

At harvest, the middle two rows of each plot were machine excavated. Tubers from the middle $2.1 \mathrm{~m}$ (2002) or $2.4 \mathrm{~m}$ (2003) of each row were hand harvested, counted, weighed, and expressed as kilograms per hectare.

Statistical analyses. Area under the senescence progress curve (AUSPC) was calculated based on the weekly disease reading (45) and divided by the number of growing degree-days (base $=10^{\circ} \mathrm{C}$, maximum $=30^{\circ} \mathrm{C}$ ) over the senescence period to generate a relative area under the senescence progress curve (RAUSPC). Inoculum density averaged across all three sampling dates was used for statistical analysis. Inoculum density and root infection (RI) were square-root transformed and RAUSPC was log-transformed after addition of one $[\ln (x+1)]$ to approximate normal distribution for these variables. Unless otherwise indicated, all statistical analyses were conducted on transformed data and back-transformed numbers are presented in tables and text.

Because the two experiments were conducted in two different fields in different years, each experiment was designated as a single environment ("experiment"). Inoculum density, RI, and RAUSPC were near zero in the noninfested plots and clearly lower than in the infested plots; therefore, analyses of variance of these three response variables were conducted using only data from plots artificially infested with $V$. dahliae. Mixed-model analysis of variance (PROC GLM; SAS release 8.02; SAS Institute, Inc., Cary, NC) was conducted, including main effect terms for experiment, block (nested in experiment), green manure type, amendment rate, and terms for all interactions of experiment, type, and rate. Because there were no significant experiment-treatment interactions for RI or RAUSPC, data from the 2002 and 2003 experiments were pooled for comparison of means. Although there was no significant experiment-treatment interaction for tuber yield, separate analyses of data from 2002 and 2003 experiments was warranted based on significant differences in experimental conditions between studies. Mean separation was conducted using the Tukey-Kramer procedure for (i) amendment rate, averaged across green manures, and (ii) green manure type, averaged across amendment rates (LSMEANS statement in PROC GLM). For the green manure type mean separation, a nonamended infested control was included as a fourth green manure type. Mean separation for individual green manure treatments was conducted using Fisher's protected 
least significant difference (MEANS statement in PROC GLM) after confirming significance of the $F$ test for difference of means. Correlations of green manure amendment rate, soil chemical and biological properties (soil $\mathrm{pH}, \mathrm{Ca}, \mathrm{K}, \mathrm{FDA}$ hydrolysis, MR, and MBC), ID, RAUSPC, and tuber yield were generated using PROC CORR.

\section{RESULTS}

Effects of experiment, green manure type, and amendment rate. Inoculum density was, on average, $2.8 \mathrm{CFU} \mathrm{g}^{-1}$ of soil higher in 2003 than 2002 (Table 1). Root infection was, on average, $3.8 \mathrm{CFU}$ $\mathrm{m}^{-1}$ root lower in 2003 than in 2002; however, because there was no significant interaction between experiment and green manure type or amendment rate, statistical analyses were performed on pooled data. Verticillium wilt severity (RAUSPC) was estimated to be $55 \%$ higher, on average, in 2003 than in 2002. For response variables ID, RI, and RAUSPC, statistical analyses were performed on pooled data because there was no significant interaction between experiment and green manure type or amendment rate. Mean total tuber yield was approximately $23 \mathrm{~kg} \mathrm{ha}^{-1}$ lower in 2003 than in 2002, due to an earlier harvest in 2003 . We determined that difference in harvest date constituted a significant difference between experimental conditions, which warranted separate analyses for the 2 years' data.

After accounting for differences between experiments, green manure rate and type had a significant effect on mean ID (Table 1; Fig. 1A and B). Although no significant differences were observed among amendment rates, the intermediate amendment rate $\left(12 \mathrm{Mg} \mathrm{ha}^{-1}\right)$ averaged across all green manure types reduced mean ID by $50 \%(P<0.01)$ relative to the nonamended control (Fig. 1A). Although no significant differences were observed among green manure types, broccoli green manures averaged across application rates reduced mean ID by $50 \%(P<0.01)$ relative to the nonamended control (Fig. 1B).
Green manure type, but not amendment rate, had an effect on RI (Table 1). No green manure type averaged across application rates reduced RI relative to the nonamended control; however, broccoli green manures averaged across all application rates resulted in 50\% $(P<0.05)$ lower RI than the Austrian winter pea green manures (Table 2). Both green manure type and amendment rate had a significant affect on RAUSPC (Table 1; Fig. 1C and D). Although no differences in mean RAUSPC were observed between green manure types, Austrian winter pea green manures averaged across application rates reduced mean disease severity by $61 \%(P$ $<0.05)$ relative to the nonamended control (Fig. 1C). The two highest amendment rates (12 and $24 \mathrm{Mg} \mathrm{ha}^{-1}$ ) reduced disease severity relative to the nonamended control by 60 and $69 \%(P<0.05$ and 0.001), respectively (Fig. 1D). The 24 $\mathrm{Mg} \mathrm{ha}^{-1}$ amendment rate resulted in $60 \%$ $(P<0.01)$ lower disease severity than the $6 \mathrm{Mg} \mathrm{ha}^{-1}$ rate. Neither green manure type nor amendment rate had a significant effect on mean tuber yield in 2002 or 2003 (Table 1).

Effects of individual green manure treatments. Six of the individual green manure treatments resulted in reduction of ID relative to the nonamended control (Table 3). After accounting for differences between experiments, green manures of Austrian winter pea applied at 12 and 24 $\mathrm{Mg} \mathrm{ha}^{-1}$ reduced ID by 35 and $38 \%(P<$ 0.05 and 0.033 ), respectively; broccoli applied at 6,12 , and $24 \mathrm{Mg} \mathrm{ha}^{-1}$ by 44,63 , and $44 \%(P<0.05,0.001$, and 0.05$)$, respectively; and Sudan grass applied at 12 $\mathrm{Mg} \mathrm{ha}^{-1}$ by $51 \%(P<0.01)$. Green manure of broccoli applied at $12 \mathrm{Mg} \mathrm{ha}^{-1}$ resulted in significantly lower ID than Austrian winter pea applied at $6 \mathrm{Mg} \mathrm{ha}^{-1}(P<0.01)$ or Sudan grass applied at $6 \mathrm{Mg} \mathrm{ha}^{-1}(P<$ $0.05)$ or $24 \mathrm{Mg} \mathrm{ha}^{-1}(P<0.05)$. Green manure of Sudan grass resulted in lower ID than Austrian winter pea applied at 6 $\mathrm{Mg} \mathrm{ha}^{-1}(P<0.05)$. Although differences in mean RI were observed between green manure treatments, no green manure treatment resulted in RI significantly different from that of the nonamended control, which fell near the center of the range of observed RI means (Table 2).

After accounting for differences between experiments compared with the nonamended control, green manure of Austrian winter pea applied at the two higher rates (12 and $24 \mathrm{Mg} \mathrm{ha}^{-1}$ ) reduced RAUSPC by 74 and $68 \%(P<0.01$ and 0.01 ), respectively (Fig. 2). In addition, Austrian winter pea applied at $12 \mathrm{Mg} \mathrm{ha}^{-1}$ resulted in lower RAUSPC than all green manure types applied $6 \mathrm{Mg} \mathrm{ha}^{-1}$. Green manure of broccoli or Sudan grass applied at the $24 \mathrm{Mg} \mathrm{ha}^{-1}$ reduced RAUSPC by 69 and $70 \%(P<0.01)$, respectively. Broccoli and Sudan grass applied at $24 \mathrm{Mg} \mathrm{ha}^{-1}$ resulted in lower RAUSPC than broccoli or Sudan grass applied at $6 \mathrm{Mg} \mathrm{ha}^{-1}$.

Total tuber yield was significantly lower in 2003 than in 2002, as evidenced by the difference in mean yields of the noninfested controls (Table 4). Among the noninfested controls in either experiment, amendment with green manure had no effect on total tuber yield. For both experiments, mean tuber yield was $20 \%$ lower in nonamended plots infested with $V$. dahliae compared with the noninfested control plots. For both experiments, no green manure treatment significantly increased mean yield relative to the nonamended infested control. In 2002, green manures of Austrian winter pea applied at all rates, broccoli applied at $24 \mathrm{Mg} \mathrm{ha}^{-1}$, and Sudan grass applied at 12 or $24 \mathrm{Mg}$ $\mathrm{ha}^{-1}$ resulted in mean yields that were not significantly different from that of the noninfested controls. In 2003, green manures of broccoli applied at $6 \mathrm{Mg} \mathrm{ha}^{-1}$ and Sudan grass applied at $24 \mathrm{Mg} \mathrm{ha}^{-1}$ resulted in mean tuber yields that were not significantly different from that of the noninfested controls.

Correlation of soil properties with ID, Verticillium wilt severity, and yield. Several soil chemical and biological properties were correlated with ID, Verticillium wilt severity, and yield (Table 5). Inoculum density was moderately, positively corre-

Table 1. Effect of experiment, green manure type (Austrian winter pea, broccoli, or Sudan grass), and amendment rate $\left(0,6,12\right.$, or $\left.24 \mathrm{Mg}^{-1}\right)$ on inoculum density (CFU g ${ }^{-1}$ soil) and root infection (CFU m${ }^{-1}$ root) by Verticillium dahliae and Verticillium wilt severity of potato as measured by the relative area under the senescence progress curve (RAUSPC) and tuber yield in 2002 and $2003^{\mathrm{z}}$

\begin{tabular}{|c|c|c|c|c|c|c|c|c|c|}
\hline \multirow[b]{2}{*}{ Source of variation } & \multirow[b]{2}{*}{ df } & \multicolumn{2}{|c|}{ Inoculum density } & \multicolumn{2}{|c|}{ Root infection } & \multicolumn{2}{|c|}{ RAUSPC } & \multicolumn{2}{|c|}{ Yield } \\
\hline & & MS & $P>F$ & MS & $P>F$ & MS & $P>F$ & MS & $P>F$ \\
\hline Experiment & 1 & 7.666 & 0.001 & 11.144 & 0.003 & 3.018 & 0.024 & $10,984.0$ & $<0.001$ \\
\hline $\begin{array}{l}\text { Block in experiment } \\
\text { Treatment }\end{array}$ & 6 & 1.309 & 0.073 & 1.438 & 0.305 & 0.583 & 0.410 & 608.0 & 0.342 \\
\hline Amendment rate & 3 & 3.756 & 0.001 & 0.105 & 0.965 & 3.433 & 0.001 & 260.1 & 0.687 \\
\hline Green manure type & 2 & 2.033 & 0.049 & 4.480 & 0.028 & 0.317 & 0.571 & 27.2 & 0.950 \\
\hline Rate $\times$ type & 4 & 0.330 & 0.721 & 1.042 & 0.475 & 0.262 & 0.760 & 309.1 & 0.672 \\
\hline Experiment $\times$ treatment & & & & & & & & & \\
\hline Experiment $\times$ rate & 3 & 0.961 & 0.222 & 0.101 & 0.967 & 0.175 & 0.816 & 296.9 & 0.640 \\
\hline Experiment $\times$ type & 2 & 0.592 & 0.400 & 2.222 & 0.159 & 0.128 & 0.796 & 590.0 & 0.333 \\
\hline Experiment $\times$ rate $\times$ type & 4 & 1.167 & 0.135 & 0.970 & 0.512 & 0.493 & 0.482 & 48.8 & 0.984 \\
\hline Pooled error & 54 & $\ldots$ & $\ldots$ & $\ldots$ & $\ldots$ & $\ldots$ & $\ldots$ & $\ldots$ & $\ldots$ \\
\hline
\end{tabular}

${ }^{\mathrm{z}} \mathrm{MS}=$ mean square. 
lated with calcium $(P<0.01)$ and moderately, negatively correlated with $\mathrm{MR}(P<$ $0.01)$ and MBC $(P<0.05)$. Verticillium wilt severity was positively correlated with soil $\mathrm{pH}(P<0.001)$ and ID $(P<$ $0.05)$ and negatively correlated with amendment rate $(P<0.001)$, potassium $(P<0.05)$, TOC $(P<0.01)$, FDA hydrolysis $(P<0.001)$, MR $(P<0.05)$, and MBC $(P<0.05)$. Yield was positively correlated with TOC $(P<0.05)$ and FDA $(P<0.001)$ and negatively correlated with soil $\mathrm{pH}(P<0.01)$ and wilt severity $(P<0.001)$. TOC, FDA hydrolysis, MR, and $\mathrm{MBC}$ were positively correlated with amendment rate. Soil $\mathrm{pH}$, calcium, and potassium were intercorrelated, reflecting a preexisting spatial gradient of these three properties in the field used in 2002. Both measures of microbial activity (FDA hydrolysis and MR) were correlated with $\mathrm{MBC}$ and TOC, although they were not correlated with each other.

\section{DISCUSSION}

The ultimate goal of using green manures to manage soilborne diseases is to reduce yield losses caused by the pathogens. In this study, no green manure treatment resulted in statistically significant improvement of potato yield compared with the nonamended control. All three green manure types, however, when applied at the highest rate $\left(24 \mathrm{Mg} \mathrm{ha}^{-1}\right)$ and Austrian winter pea applied at the intermediate rate $\left(12 \mathrm{Mg} \mathrm{ha}^{-1}\right)$ significantly reduced severity of Verticillium wilt relative to the nonamended control. Furthermore, the two highest amendment rates (24 and $\left.12 \mathrm{Mg} \mathrm{ha}^{-1}\right)$, averaged across green ma-

Table 2. Effect of green manure amendments on infection of potato roots by Verticillium dahliae (CFU $\mathrm{m}^{-1}$ root $)^{\mathrm{y}}$

\begin{tabular}{|c|c|c|c|c|c|}
\hline \multirow[b]{3}{*}{ Green manure type } & \multicolumn{5}{|c|}{ Root infection by $V$. dahliae } \\
\hline & \multicolumn{4}{|c|}{ Green manure amendment rate $\left(\mathrm{Mg} \mathrm{ha}^{-1}\right)$} & \multirow[b]{2}{*}{ Treatment mean ${ }^{\mathrm{z}}$} \\
\hline & $\mathbf{0}$ & 6 & 12 & 24 & \\
\hline Nonamended control & 7.3 & $\ldots$ & $\ldots$ & $\ldots$ & $7.3 \mathrm{ab}$ \\
\hline Austrian winter pea & $\ldots$ & 8.0 & 7.4 & 11.4 & $8.9 \mathrm{a}$ \\
\hline Broccoli & $\ldots$ & 4.4 & 5.4 & 3.7 & $4.5 \mathrm{~b}$ \\
\hline Sudan grass & $\ldots$ & 7.4 & 7.6 & 4.8 & $6.6 \mathrm{ab}$ \\
\hline
\end{tabular}

y Pooled data from 2002 and 2003 experiments.

${ }^{\mathrm{z}}$ Within the treatment means column, means followed by the same letter are not significantly different according to the Tukey-Kramer procedure $(P \leq 0.05)$.
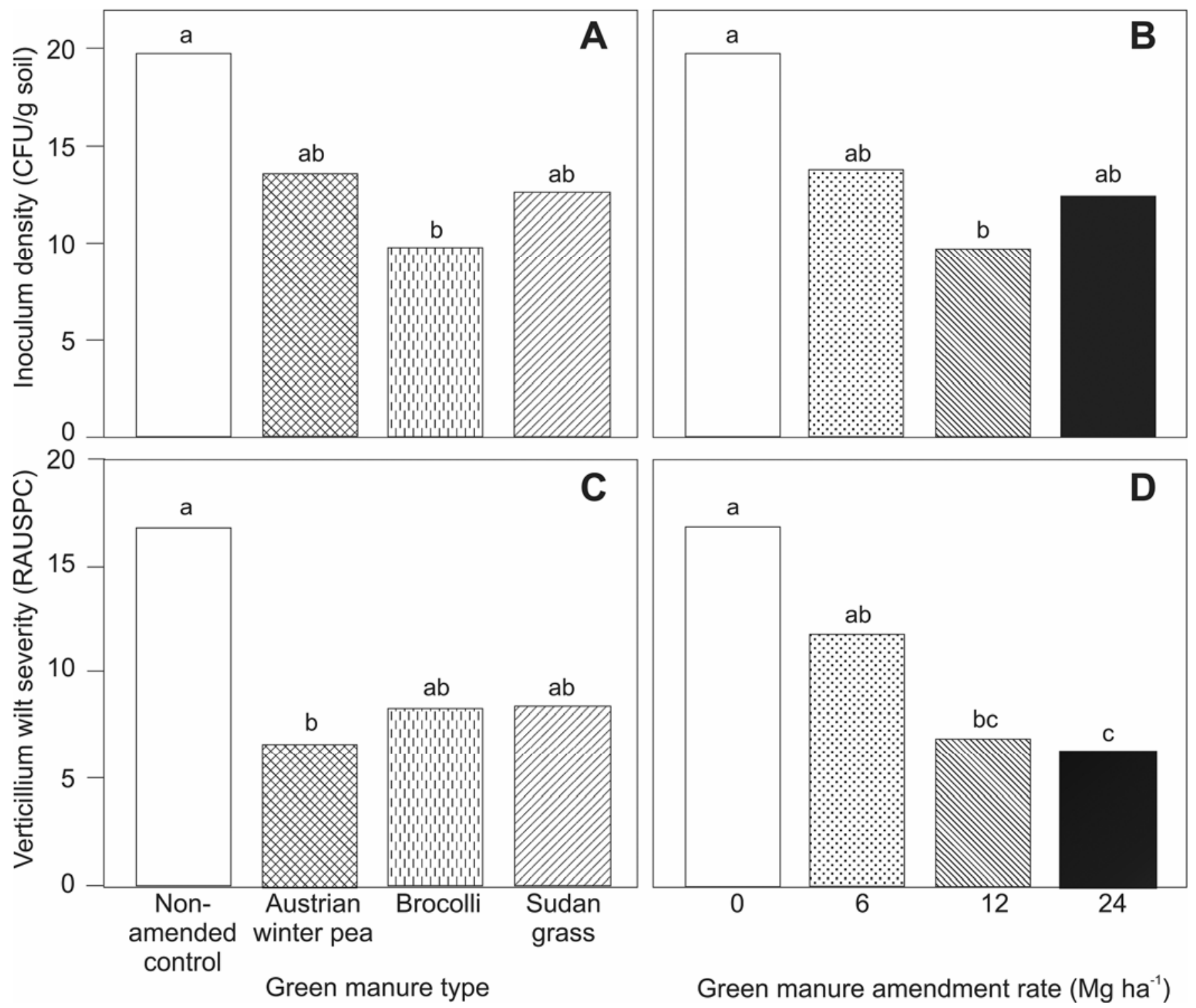

Green manure amendment rate $\left(\mathrm{Mg} \mathrm{ha}^{-1}\right)$

Fig. 1. Effect of green manure type, averaged across amendment rates, and green manure amenmdent rate, averaged across green manure types, on inoculum density of $\mathbf{A}$ and $\mathbf{B}$, Verticillium dahliae and $\mathbf{C}$ and $\mathbf{D}$, wilt severity for pooled data from 2002 and 2003 experiments. Within figures, means with different letters indicate significant differences between mean inoculum densities $(P \leq 0.05)$ according to the Tukey-Kramer multiple comparison procedure. 
nure types, resulted in significant reduction of wilt severity compared with the nonamended control.

The lack of significant impact of green manures on tuber yield even with the highest amendment rates, which is inconsistent with work by others $(11,27)$, is somewhat unexpected and suggests three possible interpretations: that the green manure treatments (i) only impact factors related to disease symptoms and not disease factors related to yield reduction; (ii) reduced wilt symptoms, but not enough to mitigate detrimental effect on yield; or (iii) affected yield, but the magnitude of impact was such that it was not statistically discernible. The former interpretation is not consistent with current understanding of how $V$. dahliae infection causes reduction of tuber yield. Briefly, V. dahliae infection is believed to reduce leaf surface area (19) as well as photosynthetic efficiency $(2,40)$ of the plant, which in turn reduces tuber bulking rate and ultimately lowers yield (24). Therefore, treatments which reduce wilt severity theoretically also should increase yield. The latter two interpretations are more consistent with theoretical understanding of the relationship between Verticillium wilt and tuber development, but are difficult to verify.

The negative correlation between disease severity and yield, taken together with the fact that several of the green manure treatments significantly reduced wilt severity, suggest that green manures had an indirect impact on yield. It is worth noting that seven of nine green manure treatments in 2002 resulted in mean yields that were nominally, although not significantly $(P>$ 0.05 ), higher than that of the nonamended infested control. Of these seven treatments, six resulted in mean yields that were lower than, but not significantly different from, that of the noninfested controls. Yield data

Table 3. Effect of individual green manure treatments on inoculum density of Verticillium dahliae (CFU g ${ }^{-1}$ soil) using pooled data from 2002 and 2003 experiments

\begin{tabular}{lc}
\hline $\begin{array}{l}\text { Green manure amendment } \\
\text { rate }\left(\mathbf{M g ~ h a}^{-\mathbf{1}}\right)\end{array}$ & $\begin{array}{c}\text { Inoculum } \\
\text { density }\end{array}$ \\
\hline $\begin{array}{l}\text { Control } \\
\text { Nonamended infested }\end{array}$ & $19.8 \mathrm{a}$ \\
Austrian winter pea & $15.8 \mathrm{ab}$ \\
6 & $12.8 \mathrm{bcd}$ \\
12 & $12.4 \mathrm{bcd}$ \\
24 & $11.1 \mathrm{bcd}$ \\
Broccoli & $7.4 \mathrm{~d}$ \\
6 & $11.2 \mathrm{bcd}$ \\
12 & $14.7 \mathrm{abc}$ \\
24 & $9.6 \mathrm{~cd}$ \\
Sudan grass & $14.1 \mathrm{abc}$ \\
6 & \\
12 & \\
24 &
\end{tabular}

${ }^{\mathrm{z}}$ Means followed by the same letter are not significantly different according to Fisher's protected least significant difference $(P \leq$ $0.05)$. from 2003, however, revealed fewer differences in mean yield between the nonamended infested control and green manure treatments. In part, this was due to the earlier harvest in 2003, which occurred in September, approximately 4 weeks earlier than in 2002. As a result, mean yield across all treatments was lower in 2003 than in 2002, reflecting the shorter period of tuber bulking over which differences in bulking rate could be expressed. The lack of clear effect of green manure treatments on yield indicates the need for further investigation of the relationship between suppression of disease and impacts on yield.

Although there was not a statistically significant yield response to green manures, several of the green manure treatments clearly reduced wilt severity. Disease suppression likely resulted in part from reduced soil populations of $V$. dahliae, as evidenced by positive correlation between ID and wilt severity in both 2002 and 2003. Some reduction in soil populations of $V$. dahliae was achieved by all three green manure types, but did not appear to be a function of amendment rate. Based on previous studies $(1,26,50,51,57)$ and knowledge of the biofumigant effect of Brassica spp. residues $(2,34,41)$, it is not surprising that broccoli green manures reduced soil populations of $V$. dahliae. Suppression of Verticillium wilt by green manures of Austrian winter pea and Sudan grass, however, have not previously been demonstrated to rely on reduction of soil populations of $V$. dahliae $(10,11,36)$. Although there is speculation that Sudan grass residue also may act as a biofumigant by release of $\rho$-hydroxybenzaldehyde and hydrogen cyanide (HCN) (53), this has not been shown to be relevant for reduction of soil populations of $V$. dahliae. Reduction of ID by Austrian winter pea or Sudan grass green manure was reported by Davis et al. (11), but only after five or four consecutive years, respectively, of incorporation. The slight, negative correlation between MR and biomass with ID observed in our studies support the possibility that reduction of $V$. dahliae soil populations by all three green manure types, including broccoli $(13,46)$, may be due to an increase in general soil microbial populations and activity stimulated by addition of organic material.

Factors other than reduction of $V$. dahliae soil populations also likely contributed to lowering of disease severity. Not all treatments which significantly lowered disease severity resulted in reduced ID and not all treatments which significantly reduced ID resulted in lowered disease severity. The two application rates of Austrian winter pea green manures which reduced disease severity (12 and $24 \mathrm{Mg}$ $\mathrm{ha}^{-1}$ ) also reduced ID. However, although broccoli applied at all three rates reduced ID, only the highest application rate lowered disease severity. Although green manure of Sudan grass applied at the intermediate rate reduced soil populations of $V$. dahliae, this treatment did not result in reduced wilt severity. Finally, although the highest application rate of Sudan grass green manure reduced wilt severity it did not significantly lower soil ID. These results, along with findings by Davis et al. (11), indicate that reduction of ID is not a necessary condition for lowering of wilt severity.

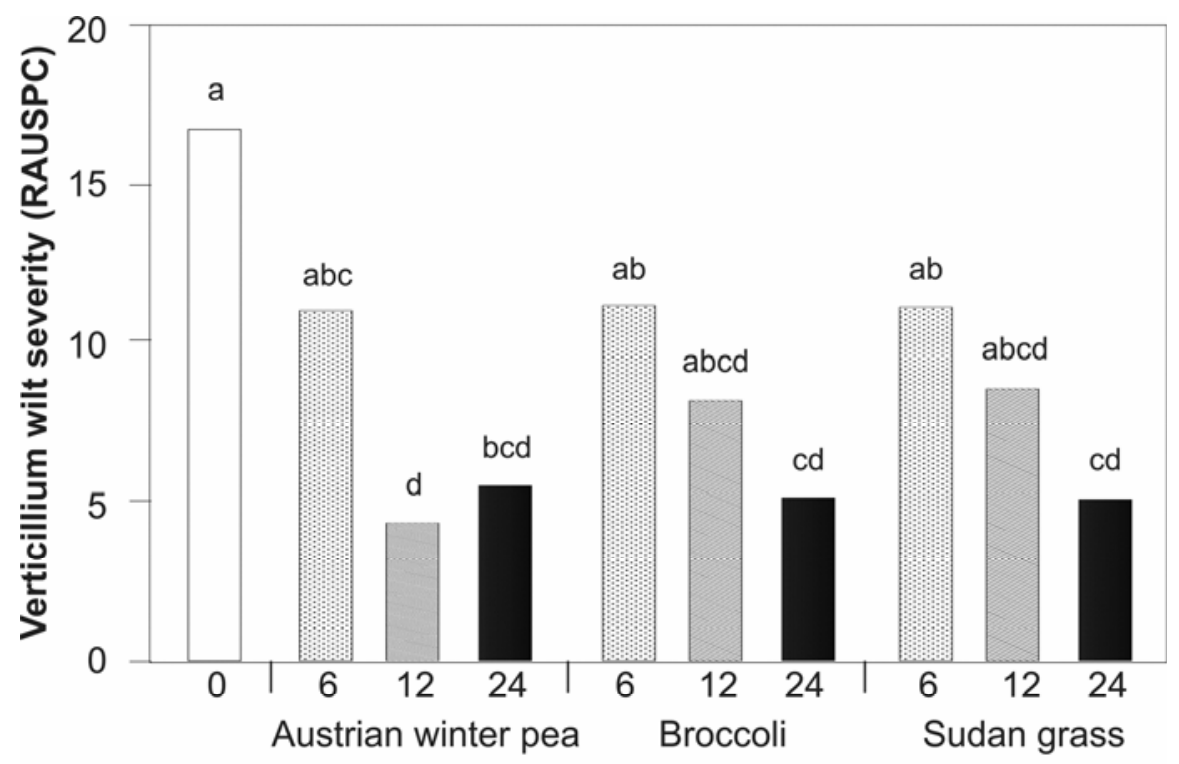

\section{Green manure amendment rate $\left(\mathrm{Mg} \mathrm{ha}^{-1}\right)$ and type}

Fig. 2. Effect of individual green manure treatments on severity of Verticillium wilt of potato, measured as relative area under the senescence property curve (RAUSPC). Means with different letters indicate significant differences between mean RAUSPC $(P \leq 0.05)$ according to the Fisher's protected least squared difference procedure. 
Disease reduction by green manures was dependent on amendment rate as well as green manure type. When applied at the lowest rate $\left(6 \mathrm{Mg} \mathrm{ha}^{-1}\right)$, none of the green manures significantly reduced disease severity relative to the nonamended infested control. When applied at the highest rate $\left(24 \mathrm{Mg} \mathrm{ha}^{-1}\right)$, however, all green manures reduced disease severity to a similar degree. At the intermediate amendment rate $\left(12 \mathrm{Mg} \mathrm{ha}^{-1}\right)$, only the Austrian winter pea green manure significantly reduced RAUSPC, indicating a difference in efficacy among green manure types. Effect of amendment rate on suppression of Verticillium wilt has been reported in only one study (10), although rate dependence of OM-mediated disease suppression has been found for other soilborne pathogens $(7,8,14,21,33,49)$. This rate dependence is consistent with our assumption that amendments alter soil physicochemical (29) or biological properties $(43,44)$, resulting in conditions unfavorable to pathogen survival or activity $(6,22)$. However, due to complex effects that OM amendments have on soil properties and host plants, identification of specific suppres- sive mechanisms not involving reduction in ID poses a substantial challenge. In 2002, abiotic factors related to soil $\mathrm{pH}$, which were preexisting and not affected by the green manure amendments, significantly contributed to the variability in wilt severity and yield. In both experiments, reduced wilt severity was correlated with increasing amendment rate, TOC, and increasing microbial biomass and activity. These observations are consistent with reports by others $(5,11,12,46,54,55)$ and suggest, although do not prove, that green manure-mediated suppression of Verticillium wilt is microbiological in nature.

In summary, these studies demonstrated consistent reduction of Verticillium wilt of potato by all three green manure types applied at the highest amendment rate (24 $\mathrm{Mg} \mathrm{ha}^{-1}$ ) and indicated a positive relationship between amendment rate and degree of disease reduction. Austrian winter pea applied at $12 \mathrm{Mg} \mathrm{ha}^{-1}$ also resulted in significant reduction of disease severity, revealing a difference in efficacy among the green manure types. Although several green manure treatments lowered soil populations of $V$. dahliae, reduction of

Table 4. Effect of individual green manure treatments on total tuber yield in 2002 and 2003

\begin{tabular}{llc}
\hline & \multicolumn{2}{c}{ Total tuber yield $\left(\mathbf{k g ~ h a}^{\mathbf{- 1}}\right)^{\mathbf{y}}$} \\
\cline { 2 - 3 } Green manure amendment rate $\left(\mathbf{M g ~ h a}^{-\mathbf{1}}\right)$ & $\mathbf{2 0 0 2}$ & $\mathbf{2 0 0 3}$ \\
\hline Control & $178 \mathrm{a}$ & $151 \mathrm{a}$ \\
$\quad$ Nonamended noninfested & $174 \mathrm{a}$ & $153 \mathrm{a}$ \\
Amended noninfested & & $122 \mathrm{~b}$ \\
$\quad$ Nonamended infested & $140 \mathrm{~b}$ & $120 \mathrm{~b}$ \\
Austrian winter pea & & $111 \mathrm{~b}$ \\
6 & $150 \mathrm{ab}$ & $120 \mathrm{~b}$ \\
12 & $154 \mathrm{ab}$ & $134 \mathrm{ab}$ \\
24 & $152 \mathrm{ab}$ & $118 \mathrm{~b}$ \\
Broccoli & & $134 \mathrm{ab}$ \\
6 & $139 \mathrm{~b}$ & $118 \mathrm{~b}$ \\
12 & $147 \mathrm{~b}$ & $128 \mathrm{~b}$ \\
24 & $151 \mathrm{ab}$ & $118 \mathrm{~b}$ \\
Sudan grass & $131 \mathrm{~b}$ & $152 \mathrm{ab}$ \\
6 & $152 \mathrm{ab}$ & \\
12 & &
\end{tabular}

${ }^{y}$ Within experiments (year), means followed by the same letter are not significantly different according to Fisher's protected least significant difference $(P \leq 0.05)$.

${ }^{\mathrm{z}}$ Plots not artificially infested with Verticillium dahliae but amended with Austrian winter pea, broccoli, or Sudan grass green manure at $12 \mathrm{Mg} \mathrm{ha}^{-1}$. disease severity was not always linked to reduced ID. Thus, other mechanisms, in addition to inoculum reduction, likely contributed to green manure-mediated reduction of Verticillium wilt severity. Significant correlation of disease severity with soil chemical factors related to soil $\mathrm{pH}$ in 2002 demonstrated abiotic disease suppression unrelated to green manure amendments. Strong negative correlation of disease severity with microbial biomass and activity measures in 2003 suggests a microbiological nature to green manuremediated suppression of Verticillium wilt. Green manure treatments did not have a clear effect on reducing yield loss in either study.

Critical issues remain which must be addressed before green manures can be considered a viable option for management of Verticillium wilt of potato (39). First, green manures must be shown to not only reduce wilt severity but also consistently reduce tuber yield losses. Second, given that the high amendment rates used in these studies $\left(24 \mathrm{Mg} \mathrm{ha}^{-1}\right)$ would be impractical for most growers, it is necessary to develop realistic green manure management practices to achieve the desired disease suppression. This may be accomplished by improving disease suppression efficiency of green manures, which may be related to a number of factors other than rate, including (i) quality or composition of plant material $(13,21)$, (ii) parts of plant incorporated (13), (iii) method of incorporation (25), or (iv) timing of amendment. Alternatively, disease suppressiveness may be developed after successive incorporation of lower rates of green manure over several years, as reported by Davis et al. (11). A clearer understanding of how different green manure factors impact disease suppression over time will enable consistent and optimized use of green manures for management of Verticillium wilt.

\section{ACKNOWLEDGMENTS}

This project was supported, in part, by the United States Department of Agriculture Regional Integrated Pest Management Grants Program for the Western Region. We thank the staff of the Central Oregon Agricultural Research Center in Madras, OR, for their assistance in preparing and managing field sites.

Table 5. Pearson's correlation coefficients $r$ for green manure amendment rate, selected soil chemical and biological properties, inoculum density of Verticillium dahliae, Verticillium wilt severity, and tuber yield using pooled data from 2002 and 2003 experiments $^{\mathrm{Z}}$

\begin{tabular}{|c|c|c|c|c|c|c|c|c|c|c|}
\hline Variables & Rate & pH & $\mathrm{Ca}$ & $\mathbf{K}$ & TOC & FDA & MR & MBC & ID & WS \\
\hline Soil pH & 0.10 & $\cdots$ & $\ldots$ & $\ldots$ & $\ldots$ & $\ldots$ & $\ldots$ & $\ldots$ & $\ldots$ & $\ldots$ \\
\hline $\mathrm{Ca}(\mathrm{ppm})$ & 0.10 & $0.49 * * * *$ & $\ldots$ & $\ldots$ & $\ldots$ & $\ldots$ & $\ldots$ & $\ldots$ & $\ldots$ & $\ldots$ \\
\hline $\mathrm{K}(\mathrm{ppm})$ & $0.23^{*}$ & $-0.36 * * * *$ & $-0.30 * * *$ & $\ldots$ & $\ldots$ & $\ldots$ & $\ldots$ & $\ldots$ & $\ldots$ & $\ldots$ \\
\hline TOC & $0.51 * * * *$ & -0.12 & 0.00 & $0.26 *$ & & $\ldots$ & $\ldots$ & $\ldots$ & $\ldots$ & $\ldots$ \\
\hline FDA & $0.39 * * *$ & -0.09 & 0.53 **** & 0.01 & $0.28 *$ & & $\ldots$ & $\ldots$ & $\ldots$ & $\ldots$ \\
\hline MR & $0.69 * * * *$ & 0.13 & -0.19 & 0.16 & $0.52 * * * *$ & 0.07 & $\ldots$ & $\ldots$ & $\ldots$ & $\ldots$ \\
\hline MBC & $0.46 * * * *$ & 0.15 & 0.07 & -0.03 & $0.41 * * * *$ & $0.32 * * * *$ & $0.72 * * * *$ & $\ldots$ & $\ldots$ & $\ldots$ \\
\hline ID & -0.18 & 0.02 & $0.29 * * *$ & -0.04 & -0.15 & 0.20 & $-0.38 * * * *$ & $-0.28 *$ & . & $\ldots$ \\
\hline WS & $-0.42 * * * *$ & $0.43 * * * *$ & 0.22 & $-0.26 *$ & $-0.40 * * * *$ & $-0.40 * * * *$ & $-0.27 *$ & $-0.27 *$ & $0.28 *$ & 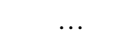 \\
\hline Tuber yield & 0.13 & $-0.36 * * *$ & 0.05 & 0.13 & $0.28 *$ & $0.46 * * * *$ & 0.04 & 0.20 & 0.02 & $-0.53 * * * *$ \\
\hline
\end{tabular}

${ }^{\mathrm{z}}$ Variables $=$ Soil property, pathogen, disease, and yield; Rate $=$ green manure amendment rate; TOC $=$ total organic carbon; FDA $=$ fluorescein diacetate hydrolysis; $\mathrm{MR}=$ microbial respiration; $\mathrm{MBC}=$ microbial biomass carbon; $\mathrm{ID}=$ inoculum density; $\mathrm{WS}=$ Wilt severity; and *, **, ***, and **** indicate significance at $P \leq 0.05,0.01,0.001$, and 0.0001 , respectively. 


\section{LITERATURE CITED}

1. Berlanger, I. E. 2000. Effect of broccoli green manure, soil solarization, and isolates of Verticillium dahliae on Verticillium wilt of agronomic and nursery crops. M.S. thesis, Oregon State University, Corvallis.

2. Bowden, R. L., Rouse, D. I., and Sharkey, T. D. 1990. Mechanism of photosynthesis decrease by Verticillium dahliae in potato. Plant Physiol. 94(3):1048-1055.

3. Brown, P. D., and Morra, M. J. 1997. Control of sol-borne plant pests using glucosinolatecontaining plants. Pages 167-231 in: Advances in Agronomy. D. L. Sparks, ed. Academic Press, San Diego, CA.

4. Butterfield, E., and DeVay, J. E. 1977. Reassessment of soil assays for Verticillium dahliae. Phytopathology. 67:1073-1078.

5. Conn, K. L., and Lazarovits, G. 1999. Impact of animal manures on Verticillium wilt, potato scab, and soil microbial populations. Can. J. Plant Pathol. 21:81-92.

6. Cook, R. J., and Baker, K. F. 1983. The Nature and Practice of Biological Control of Plant Pathogens. American Phytopathological Society Press, St. Paul, MN.

7. da Costa, J. L. S., Menge, J. A., and Casale, W. L. 1996. Investigations on some of the mechanisms by which bioenhanced mulches can suppress Phytophthora root rot of avocado. Microbiol. Res. 151:183-192.

8. Darby, H. M. 2003. Soil organic matter management and root health. Ph.D. dissertation, Oregon State University, Corvallis.

9. Davis, J. R., Huisman, O. C., Westermann, D. T., Everson, D. O., Schneider, A. T., and Sorensen, L. H. 1999. Control of Verticillium wilt of the Russet Burbank potato with corn and barley. (Abstr.) Am. J. Potato. Res. 76:367.

10. Davis, J. R., Huisman, O. C., Westermann, D. T., Everson, D. O., Schneider, A. T., and Sorensen, L. H. 1999. Increased yield and quality of Russet Burbank with Sudan grass and associations with soil nutrients. (Abstr.) Am. J. Potato. Res. 76:367.

11. Davis, J. R., Huisman, O. C., Westermann, D. T., Hafez, S. L., Everson, D. O., Sorensen, L. H., and Schneider, A. T. 1996. Effects of green manures on Verticillium wilt of potato. Phytopathology. 86(5):444-453.

12. Davis, J. R., Huisman, O. C., Westermann, D. T., Sorensen, L. H., Schneider, A. T., and Stark, J. C. 1994. The influence of cover crops on the suppression of Verticillium wilt of potato. Pages 332-341 in: Advances in Potato Pest Biology and Management. G. W. Zehnder, M. L. Powelson, R. K. Jannson, and K. V. Ramay, eds. American Phytopathological Society Press, St. Paul, MN.

13. DeBodes, J., Clewes, E., DeBacker, G., and Höffe, M. 2005. Lignin is involved in the reduction of Verticillium dahliae var. longisporum inoculum in soil by crop residue incorporation. Soil Biol. Biochem. 37:301-309.

14. Dickerson, G. W. 1999. Damping off and root rot. Biocycle 40:62-63.

15. Easton, G. D., and Nagle, M. E. 1987. Verticillium wilt control and enhanced potato production flowing cropping with green peasudangrass rotation. (Abstr.) Can. J. Plant Pathol. 9:80.

16. Evans, G., and Gleeson, A. C. 1973. Observations on the origin and nature of Verticillium dahliae colonizing plant roots. Aust. J. Biol. Sci. 26:151-161.

17. Fontaneli, R. S., Sollenberger, L. E., and Staples, C. R. 2001. Yield, yield distribution, and nutritive value of intensively managed warm-season annual grasses. Agron. J. 93:1257-1262.

18. Gaudreault, S. M., Powelson, M. L., Christensen, N. W., and Crowe, F. J. 1995. Soil water pressure and Verticillium dahliae interactions on potato. Phytopathology 85(12):1542-1546.

19. Harrison, J. A. C., and Isaac, I. 1968. Leaf-area development in King Edward potato plants inoculated with Verticillium albo-atrum and V. dahliae. Ann. Appl. Biol. 61:217-230.

20. Hildebrand, A. A., and West, P. M. 1941. Strawberry root rot in relation to microbiological changes induced in root rot soil by the incorporation of certain cover crops. Can. J. Res. C. 19:183-198.

21. Hoitink, H. A. J., and Boehm, M. J. 1999. Biocontrol within the context of soil microbial communities: a substrate-dependent phenomenon. Annu. Rev. Phytopathol. 37:427-446.

22. Höper, H., and Alabouvette, C. 1996. Importance of physical and chemical soil properties in the suppressiveness of soils to plant diseases. Eur. J. Soil Biol. 32(1):41-58.

23. Jenkinson, D. S., and Powlson, D. S. 1976. Effects of biocidal treatments on metabolism in soil. V. A method for measuring the soil biomass. Soil Biol. Biochem. 8:209-213.

24. Johnson, K. B. 1988. Modeling the influences of plant infection rate and temperature on potato foliage and yield losses caused by Verticillium dahliae. Phytopathology 79(9):1198-1205.

25. Kirkegaard, J. 2001. Does incorporation strategy hold the key to biofumigation success? CSIRO: Horticulture Biofumigation Update. No. 14. Online publication.

26. Koike, S. T., and Subbarao, K. V. 2000. Broccoli residues can control Verticillium wilt of cauliflower. Calif. Agric. 54(3):30-33.

27. LaMondia, J. A., Gent, M. P. N., Ferrandino, F. J., Elmer, W. H., and Stoner, K. A. 1999. Effect of compost amendment or straw mulch on potato early dying disease. Plant Dis. 83(4):361366.

28. Lazarovits, G., Tenuta, M., and Conn, K. L. 2001. Organic amendments as a disease control strategy for soilborne diseases of highvalue agricultural crops. Australas. Plant Pathol. 30:111-117.

29. MacRae, R. J., and Mehuys, G. R. 1985. The effect of green manuring on the physical properties of temperate-area soils. Adv. Soil Sci. 3:71-94.

30. Mahler, R. L., and Auld, D. L. 1989. Evaluation of the green manure potential of Austrian winter peas in northern Idaho. Agron. J. 81:258-264.

31. Millard, W. A., and Taylor, C. B. 1927. Antagonism of microorganisms as the controlling factor in the inhibition of scab by green manuring. Ann. Appl. Biol. 14:202-215.

32. Nelson, D. W., and Sommers, L. E. 1996. Total carbon, organic carbon, and organic matter. In: Methods of Soil Analysis. Part 3. Chemical Methods. J. M. Bingham, ed. SSSA, Inc., Madison, WI.

33. Noble, R., and Coventry, E. 2005. Suppression of soil-borne plant diseases with composts: A review. Biocontrol Sci. Technol. 15:3-20.

34. Olivier, C., Vaugh, S. F., Mizubuti, E. S. G., and Loria, R. 1999. Variation in allyl isothiocyanate production within Brassica species and correlation with fungicidal activity. J. Chem. Ecol. 25:2687-2701

35. Parks, R. L. 1998. Influence of Sudangrass green manure on microorganisms and early dying of potatoes in two soils. M.S. thesis, Oregon State University, Corvallis.

36. Pinkerton, J. N., Ivors, K. L., Miller, M. L., and Moore, L. W. 2000. Effect of soil solarization and cover crops on populations of selected soilborne plant pathogens in western Oregon. Plant Dis. 84(9):952-960.

37. Powelson, M. L., and Rowe, R. C. 1993. Biology and management of early dying of potatoes. Annu. Rev. Phytopathol. 31:111-126.

38. Rotenburg, D., and Cooperband, L. 2002. Disease incidence and severity in potatoes grown in composts and paper mill residual. Pages 47-52 in: Proc. Wisc. Annu. Potato Meetings 2002, Stevens Point, WI.

39. Rowe, R. C., and Powelson, M. L. 2002. Po- tato early dying: management challenges in a changing production environment. Plant Dis. 86(11):1184-1193.

40. Saeed, I. A. M., MacGuidwin, A. E., and Rouse, D. I. 1997. Disease progress based on effects of Verticillium dahliae and Pratylenchus penetrans on gas exchange in Russet Burbank potato. Phytopathology 87:440-445.

41. Sarwar M., Kirkegaard, J. A., Wong, P. T. W., and Desmarchelier, J. M. 1998. Biofumigation potential of brassicas. III. In vitro toxicity of isothiocyanates to soil-borne fungal pathogens. Plant Soil 201:103-112.

42. Schnürer, J., and Rosswall, T. 1982. Fluorescein diacetate hydrolysis as a measure of total microbial activity in soil and litter. Appl. Environ. Microbiol. 43:1256-1261.

43. Schutter, M. E., and Dick, R. P. 2001. Shifts in substrate utilization potential and structure of soil microbial communities in response to carbon substrates. Soil Biol. Biochem. 33(11):1481-1491.

44. Schutter, M. E., and Dick, R. P. 2002. Microbial community profiles and activities among aggregates of winter fallow and cover-cropped soil. Soil Sci. Soc. Am. J. 66(1):142-153.

45. Shaner, G., and Finney, R. E. 1977. The effect of nitrogen fertilization on the expression of slow-mildewing resistance in Knox wheat. Phytopathology 67:1051-1056.

46. Shetty, K. G., Subbarao, K. V., Huisman, O. C., and Hubbard, J. C. 2000. Mechanism of broccoli-mediated Verticillium wilt reduction in cauliflower. Phytopathology 90(3):305-310.

47. Snyder, W. C., and Smith, S. N. 1981. Current status. Pages 25-50 in: Fungal Wilt Diseases of Plants. M. E. Mace, ed. Academic Press, London.

48. Sorensen, L. H., Schneider, A. T., and Davis, J. R. 1991. Influence of sodium polygalacturonate sources and improved recovery of Verticillium spp. from soil. (Abstr.). Phytopathology 81:1347.

49. Stone, A. G., Scheuerell, S. J., and Darby, H. M. 2004. Suppression of soilborne diseases in field agricultural systems: organic matter management, cover cropping, and cultural practices. Pages 131-178 in: Soil Organic Matter in Sustainable Agriculture. F. Magdoff and R. Weil, eds. CRC Press. Boca Raton, FL.

50. Subbarao, K. V., and Hubbard, J. C. 1996. Interactive effects of broccoli residue and temperature on Verticillium dahliae microsclerotia in soil and on wilt in cauliflower. Phytopathology 86:1303-1310.

51. Subbarao, K. V., Hubbard, J. C., and Koike, S. T. 1998. Evaluation of broccoli residue incorporation in field soil for Verticillium wilt control in cauliflower. Plant Dis. 83(2):124-129.

52. Tenuta, M., Conn, K. L., and Lazarovitz, G. 2002. Volatile fatty acids in liquid swine manure can kill microsclerotia of Verticillium dahliae. Phytopathology 92(5):548-552.

53. Widmer, T. L., and Abawi, G. S. 2000. Mechanism of suppression of Meloidogyne hapla and its damage by a green manure of Sudan grass Plant Dis. 84(5):562-568.

54. Wiggins, B. E., and Kinkel, L. L. 2005. Green manures and crop sequences influence potato diseases and pathogen inhibitory activity of indigenous streptomycetes. Phytopathology 95(2): 178-185.

55. Wilhelm, S. 1951. Effect of various soil amendments on the inoculum potential of the Verticillium wilt fungus. Phytopathology 41:684-690

56. Wilhelm, S. 1955. Longevity of the Verticillium wilt fungus in the laboratory and field. Phytopathology 45:180-181.

57. Xiao, C. L., Subbarao, K. V., Schulbach, K. F., and Koike, S. T. 1998. Effects of crop rotation and irrigation on Verticillium dahliae microsclerotia in soil and wilt in cauliflower. Phytopathology 88(10):1046-1055. 